\title{
A FRAMEWORK FOR VALUATION AND PRIORITIZATION OF PATENTS USING A COMBINED MADM APPROACH. CASE STUDY: NANOTECHNOLOGY
}

\author{
Jalil Heidary Dahooie, Navid Mohammadi, Mehdi Mohammadi, \\ Parisa Shahmohammadi, Zenonas Turskis, Jonas Šaparauskas
}

\section{Introduction}

Intangible assets play a significant role in other areas, in particular, developing the strategy and creating a patent portfolio for organizations (Wang, García, Guijarro, \& Moya, 2011). In general, innovation can be considered as the engine for developing enterprise competitiveness. To this end, the research and development unit of organizations is focused on inventions and their legal protection (Lee, Park, \& Jang, 2015). Today, a significant portion of the assets of organizations is intangible assets (Bishop, 2003). Intellectual property is typically defined as a set of products that are protected under the laws relating to patents, copyrights, trademarks, and trade secrets (Kumar, 1994). Studies show that three main advantages of patents, which add to the importance of their registration, are to encourage the creation of knowledge and innovation, to maintain knowledge in the organization, and to protect identity and characteristics of change (Kumar, 1994). Accordingly, determining the value of patents is a critical factor which plays a vital role in the success of organizations (Anderson, 1992). A patent is a set of exclusive rights granted by a country to an inventor for a limited period, in exchange for detailed public disclosure of the invention (WIPO, 2008). Organizations own a large number of these registered technologies and inventions (PCT, 2011). Successful exploitation and management of these patents is a critical factor in the business strategy of the organization (IP4Inno, 2008). In this regard, patent valuation and prioritization is one of the main activities related to the management of intellectual property assets in an organization. Indeed, knowing the economic value and the importance of intellectual property rights helps to make strategic decisions about the assets of the organization and also facilitates intellectual property commercialization and transactions (IP4Inno, 2008).

The correct and accurate valuation of patents is a concern that has led many researchers to identify the criteria for this purpose (Lee \& Sohn, 2016; Fischer \& Leidinger, 2014). There are different approaches to value and prioritize patents (Parr \& Smith, 1994), including costoriented (Drews, 2001), market-oriented (Daryl \& Drews, 2006), income-oriented (Kamiyama, Sheehan, \& Martinez, 2006) and real options approach (Pitkethly, 1999). These methods cannot calculate the economic value of patents and intangible assets, and their results are different (Young-Ki, Seung-Jun, \& Seong-Taek, 2016). In particular, the cost-oriented approach does not have the ability to calculate potential future profit; market-oriented approach can be measured in theory, but in practice, there is generally no market to compare the value of the desired patent; and the income-oriented method is also valid in opinion, but in practice there is no ability to calculate future cash flow (Hytönen \& Jarimo, 2010). On the other hand, researchers have found that valuation and prioritization of patents are not sufficient enough if we only consider a particular criterion (forward citations, backward citations, patent's life, etc.) (Reitzig, 2004).

Accordingly, a wide range of criteria should be considered for this purpose (Wang, García, Guijarro, \& Moya, 2011). Given the need to address different rules and the difference between the importance of each of these criteria, multi-attribute decision-making (MADM) methods can be beneficial (Chiu \& Chen, 2007; Dahooie, Vanaki, Mohammadi, \& Firoozfar, 2018). MADM approaches make 
it possible to overcome the complexity of this issue and facilitate decision-making on patents and determining their strategic position (Wang, García, Guijarro, \& Moya, 2011). Another approach recently considered by the researchers in the area of technology valuation is MADM approach (Sivilevičius, Zavadskas, \& Turskis, 2008; Zavadskas, Turskis, Volvačiovas, \& Kildiene, 2013; Zavadskas, Antucheviciene, Saparauskas, \& Turskis, 2013). The logic of these methods relies on the principle that each of the patent indicators calculates a part of the value of the option, and therefore, it is necessary to consider all the dimensions and indicators together when calculating the performance of each patent (Mattei, 2009; Young-Ki, Seung-Jun, \& Seong-Taek, 2016). This approach takes into account various valuation indicators, determines the value and position of patents (Chiu \& Chen, 2007). So far little attention has been paid to this approach, and traditional methods have been mainly used for the valuation of patents. This paper provides a framework for using MADM methods to value patents and fills the gaps in the literature is as follows:

- Intending to offer a comprehensive patent assessment model, the criteria emphasized in past researches should be summarized and an approach should be proposed that in addition to gathering the views of the experts on the developed model can localize appropriately to the conditions of the case study.

- Since the decision-making methods previously used in the few related studies are complicated and time-consuming, this study offers to use multi-attribute decisionmaking methods, which in addition to easiness, have the necessary efficiency and can take into account the views of the experts in the evaluation process.

- This research uses real data registered in the form of patents, in contrast to many previous studies that only consider the expert opinions to evaluate the alternatives.

In the first step of the research, the indicators of prioritization and valuation of patents have been extracted from the literature. Then, using the opinions of the experts in the field of technology management as well as the field of nanotechnology, these indicators have been finalized based on the framework of the fuzzy Delphi method and categorized according to these opinions as well as general categories in prioritization and valuation articles. Then, using the views of the experts in both areas, the weight of the indicators has been obtained based on a MADM method, SWARA. In the end, using the ARAS method, valuation and prioritization of patents in the field of nanotechnology (12 patents), registered at the Iranian Administration of Registration of Documents in 2016, has been addressed.

In the first section after the introduction, the background of this research is reviewed, and the final indicators are taken from the literature. Then, the research methodology and MADM approaches used in this research are described. Later, after describing the case study, the data analysis is done to weight and prioritize the patents. Finally, the conclusions of the research are expressed.

\section{Background Review}

As previously stated, prioritization and valuation of patents hold a special place in managerial decisions, especially in knowledge-based organizations (Spinello, 2007). Besides, this valuation requires simultaneous attention to multiple criteria affecting the value of patents (Reitzig, 2004). With the help of multi-attribute decision making, the intellectual property valuation approach has been used in several articles to increase the accuracy of decision making on these assets (Chiu \& Chen, 2007; Young-Ki, Seung-Jun, \& Seong-Taek, 2016). This section of the paper tries to review the previous articles in the field of prioritization and evaluation of patents to explain the research gap in this area and derive the initial list of criteria used. Tab. 1 shows the most critical researches in terms of purpose, principles, method(s), as well as the results. Because the details of the criteria have been showed in Tab. 3, we summarized the criteria set of each paper in Tab. 1.

In addition to the studies described in the table above, other researchers have also tried to identify the criteria for valuation and prioritization of patents (Wu \& Tseng, 2006; Ernst, Legler, \& Lichtenthaler, 2010; U.S. Patent Application Patent No. 10/615,068, 2003; Kochupillai \& Smith, 2007; Fallah, Fishman, \& Reilly, 2011; van der Vorst, 2011; Kopczewska \& Kopyt, 2014; Falk \& Kenneth, 2017; Hirschey \& Richardson, 2001; Fabry, Ernst, Langholz, \& Köster, 2006). 
Tab. 1: Literature review (Part 1)

\begin{tabular}{|c|c|c|c|c|}
\hline $\begin{array}{c}\text { Authors } \\
\text { (year) }\end{array}$ & Purpose & Criteria & Method & Results \\
\hline $\begin{array}{l}\text { (Lee \& Sohn, } \\
\text { 2016) }\end{array}$ & $\begin{array}{l}\text { Analysis } \\
\text { of patent } \\
\text { portfolio }\end{array}$ & $\begin{array}{l}\text { Portfolio size, \# of claims, } \\
\text { backward citations, } \\
\text { forward citations, } \\
\text { technology growth rates, } \\
\text {... }\end{array}$ & Fuzzy AHP & $\begin{array}{l}\text { Marketability and } \\
\text { technology dimensions } \\
\text { have almost the same } \\
\text { weight. }\end{array}$ \\
\hline $\begin{array}{l}\text { (Chiu \& Chen, } \\
\text { 2007) }\end{array}$ & $\begin{array}{l}\text { Valuation } \\
\text { of patents }\end{array}$ & $\begin{array}{l}\text { The essence of technology, } \\
\text { the cost dimensions, } \\
\text { the product market, ... }\end{array}$ & AHP & $\begin{array}{l}\text { The cost dimensions are } \\
\text { the most important. }\end{array}$ \\
\hline $\begin{array}{l}\text { (Collan, } \\
\text { Fedrizzi, \& } \\
\text { Luukka, 2013) } \\
\end{array}$ & \begin{tabular}{|l|} 
Rank \\
patents
\end{tabular} & $\begin{array}{l}\text { Strategic fit, technical } \\
\text { quality, licensing potential, } \\
\ldots\end{array}$ & \begin{tabular}{|l|} 
Fuzzy \\
TOPSIS-AHP
\end{tabular} & $\begin{array}{l}\text { The use of technical } \\
\text { experts' opinions increases } \\
\text { the accuracy of valuation. }\end{array}$ \\
\hline (Huang, 2016) & $\begin{array}{l}\text { Analysis of } \\
\text { the patent } \\
\text { portfolio }\end{array}$ & $\begin{array}{l}\text { \# of patents granted, R\&D } \\
\text { human resources, forward } \\
\text { and backward citations, ... }\end{array}$ & $\begin{array}{l}\text { TOPSIS and } \\
\text { GRA }\end{array}$ & $\begin{array}{l}\text { GRA is suitable for } \\
\text { analyzing sequential-type } \\
\text { data. }\end{array}$ \\
\hline $\begin{array}{l}\text { (Young-Ki, } \\
\text { Seung-Jun, \& } \\
\text { Seong-Taek, } \\
\text { 2016) }\end{array}$ & \begin{tabular}{|l|} 
Indicators of \\
technology \\
valuation
\end{tabular} & $\begin{array}{l}\text { size of the portfolio, } \\
\text { the number of claims, } \\
\text { the backward citations, } \\
\text { the forward citations, ... }\end{array}$ & AHP & $\begin{array}{l}\text { Dimensions of technology } \\
\text { quality and technology } \\
\text { growth rate contribute } \\
\text { to } 58 \% \text { in technology } \\
\text { valuation. } \\
\end{array}$ \\
\hline $\begin{array}{l}\text { (Fischer \& } \\
\text { Leidinger, } \\
\text { 2014) }\end{array}$ & \begin{tabular}{|l} 
Patent \\
valuation
\end{tabular} & $\begin{array}{l}\text { Patent family size, the } \\
\text { \# of forwarding citations, } \\
\text { the \# of IPC classes, ... }\end{array}$ & $\begin{array}{l}\text { Statistical } \\
\text { methods }\end{array}$ & $\begin{array}{l}\text { Forward quotes and family } \\
\text { size are strongly related to } \\
\text { patent value. }\end{array}$ \\
\hline $\begin{array}{l}\text { (Chiesa \& } \\
\text { Gilardoni, } \\
\text { 2005) }\end{array}$ & $\begin{array}{l}\text { Valuation of } \\
\text { technology } \\
\text { in buy- } \\
\text { cooperate- } \\
\text { sell } \\
\text { decisions }\end{array}$ & $\begin{array}{l}\text { The current value } \\
\text { of project cash flows, } \\
\text { deviation of project value } \\
\text { index, project investment } \\
\text { cost, ... }\end{array}$ & $\begin{array}{l}\text { Statistical } \\
\text { methods }\end{array}$ & $\begin{array}{l}\text { To evaluate the patent, } \\
\text { you must first identify } \\
\text { the scope of the patent } \\
\text { and its purpose and then } \\
\text { consider different valuation } \\
\text { approaches together. }\end{array}$ \\
\hline $\begin{array}{l}\text { (Park \& Park, } \\
\text { 2004) }\end{array}$ & $\begin{array}{l}\text { Technology } \\
\text { valuation }\end{array}$ & $\begin{array}{l}\text { A total of } 13 \text { indicators in } \\
\text { four dimensions: intrinsic, } \\
\text { application, value-type, } \\
\text { and value-size. }\end{array}$ & $\begin{array}{l}\text { Statistical } \\
\text { methods }\end{array}$ & $\begin{array}{l}\text { In evaluating the patent, } \\
\text { the opinions of field } \\
\text { experts should be used. }\end{array}$ \\
\hline $\begin{array}{l}\text { (Hytönen \& } \\
\text { Jarimo, 2010) }\end{array}$ & $\begin{array}{l}\text { Technology } \\
\text { valuation }\end{array}$ & $\begin{array}{l}\text { The size and life cycle } \\
\text { of the potential market, } \\
\text { the distinct initial value, ... }\end{array}$ & $\begin{array}{l}\text { Scenario } \\
\text { approach }\end{array}$ & $\begin{array}{l}\text { Combining financial and } \\
\text { non-financial indicators } \\
\text { reduces the uncertainty } \\
\text { inherent in the nature of } \\
\text { the valuation. } \\
\end{array}$ \\
\hline $\begin{array}{l}\text { (Lee, Park, \& } \\
\text { Jang, 2015) }\end{array}$ & $\begin{array}{l}\text { Identifying } \\
\text { valuation } \\
\text { indicators }\end{array}$ & $\begin{array}{l}\text { The number of patent } \\
\text { applications, the number } \\
\text { of citations and the cost } \\
\text { of R\&D }\end{array}$ & $\begin{array}{l}\text { Statistical } \\
\text { methods }\end{array}$ & $\begin{array}{l}\text { It is necessary to use } \\
\text { the criteria in different } \\
\text { approaches of patent } \\
\text { valuation. }\end{array}$ \\
\hline $\begin{array}{l}\text { (Oh, Lei, Mitra, } \\
\text { \& Yen, 2012) }\end{array}$ & $\begin{array}{l}\text { Evaluating } \\
\text { patents }\end{array}$ & Citations & $\begin{array}{l}\text { regression } \\
\text { analysis }\end{array}$ & Ranking patents \\
\hline $\begin{array}{l}\text { (Hong, Seo, } \\
\text { Kim, \& Kang, } \\
\text { 2010) }\end{array}$ & $\begin{array}{l}\text { Investigating } \\
\text { different } \\
\text { patent } \\
\text { valuation } \\
\text { indicators }\end{array}$ & $\begin{array}{l}\text { technology completeness } \\
\text { level, technology difficulty } \\
\text { level, technology } \\
\text { originality, ... }\end{array}$ & $\begin{array}{l}\text { Statistical } \\
\text { methods }\end{array}$ & $\begin{array}{l}\text { Various financial and non- } \\
\text { financial indicators should } \\
\text { be considered for valuation } \\
\text { of patents. }\end{array}$ \\
\hline
\end{tabular}




\section{Tab. 1: $\quad$ Literature review (Part 2)}

\begin{tabular}{|c|c|c|c|c|}
\hline $\begin{array}{l}\text { Authors } \\
\text { (year) }\end{array}$ & Purpose & Criteria & Method & Results \\
\hline (Mattei, 2009) & $\begin{array}{l}\text { Valuation } \\
\text { of patents }\end{array}$ & $\begin{array}{l}\text { \# of inventors, family size, } \\
\text { patent scope, patent width, } \\
\text { renewability, forward / } \\
\text { backward citations, ... }\end{array}$ & $\begin{array}{l}\text { Statistical } \\
\text { analysis }\end{array}$ & $\begin{array}{l}\text { Predicting the value } \\
\text { of patents with } \\
\text { conventional approaches } \\
\text { such as market-oriented } \\
\text { has a lot of errors. }\end{array}$ \\
\hline $\begin{array}{l}\text { (Martinez-Ruiz } \\
\text { \& Aluja-Banet, } \\
\text { 2009) } \\
\end{array}$ & $\begin{array}{l}\text { Indicators } \\
\text { for patent } \\
\text { valuation. }\end{array}$ & $\begin{array}{l}\text { Citations received, grant } \\
\text { (protection level), size of } \\
\text { the patent family, ... } \\
\end{array}$ & $\begin{array}{l}\text { Statistical } \\
\text { methods }\end{array}$ & $\begin{array}{l}\text { Indicators for patent } \\
\text { valuation }\end{array}$ \\
\hline $\begin{array}{l}\text { (Ha, Liu, Cho, } \\
\text { \& Kim, 2015) }\end{array}$ & $\begin{array}{l}\text { Finding } \\
\text { patent value } \\
\text { indicators. }\end{array}$ & $\begin{array}{l}\text { Knowledge stock, } \\
\text { the technological scope, } \\
\text { the international scope... }\end{array}$ & PLS & $\begin{array}{l}\text { The criteria for the technical } \\
\text { domain (\# of claims and } \\
\text { IPCs) and the international } \\
\text { property domain are most } \\
\text { important. }\end{array}$ \\
\hline $\begin{array}{l}\text { (Kwon, Ryu, \& } \\
\text { Park, 2013) }\end{array}$ & $\begin{array}{l}\text { Prioritizing } \\
\text { patents }\end{array}$ & $\begin{array}{l}\text { Activities related to } \\
\text { patents, technology life } \\
\text { cycle, ... }\end{array}$ & $\begin{array}{l}\text { Delphi and } \\
\text { Data mining }\end{array}$ & $\begin{array}{l}\text { Experts' opinions have an } \\
\text { effective role in confirming } \\
\text { the results from the } \\
\text { clustering of technologies. }\end{array}$ \\
\hline $\begin{array}{l}\text { (Littmann- } \\
\text { Hilmer \& } \\
\text { Kuckartz, } \\
\text { 2009) }\end{array}$ & $\begin{array}{l}\text { Ranking the } \\
\text { patents }\end{array}$ & $\begin{array}{l}\text { Three main dimensions } \\
\text { are patent strength, } \\
\text { commercial potential and } \\
\text { technological potential }\end{array}$ & $\begin{array}{l}\text { Text mining } \\
\text { approach }\end{array}$ & $\begin{array}{l}\text { The analysis and ranking } \\
\text { of patents provide useful } \\
\text { information on } R \& D \\
\text { planning and technology } \\
\text { strategy. }\end{array}$ \\
\hline $\begin{array}{l}\text { (Grimaldi, } \\
\text { Cricelli, Di } \\
\text { Giovanni, \& } \\
\text { Rogo, 2015) }\end{array}$ & $\begin{array}{l}\text { Portfolio } \\
\text { Analysis }\end{array}$ & $\begin{array}{l}\text { Relative market share, } \\
\text { probable market growth, } \\
\text { profit margin, market } \\
\text { value, ... }\end{array}$ & BCG matrix & $\begin{array}{l}\text { The model presented in } \\
\text { this article can help SMEs } \\
\text { decide on their patents. }\end{array}$ \\
\hline (Reitzig, 2004) & $\begin{array}{l}\text { Strategic } \\
\text { planning of } \\
\text { technology }\end{array}$ & $\begin{array}{l}\text { The \# of patent claims, } \\
\text { the \# of patent citations, } \\
\text { market coverage, strategic } \\
\text { relevance, ... }\end{array}$ & $\begin{array}{l}\text { Statistical } \\
\text { methods }\end{array}$ & $\begin{array}{l}\text { The opinions of experts } \\
\text { have a significant role in } \\
\text { determining the position } \\
\text { and status of each patent. }\end{array}$ \\
\hline $\begin{array}{l}\text { (Lukach \& } \\
\text { Lukach, 2007) }\end{array}$ & $\begin{array}{l}\text { Validating } \\
\text { indicators } \\
\text { by patent } \\
\text { strategies }\end{array}$ & $\begin{array}{l}\text { Patent age, the market } \\
\text { value of the corporation, } \\
\text { backward citations, } \\
\text { forward citations, ... }\end{array}$ & $\begin{array}{l}\text { standard } \\
\text { deviation-t- } \\
\text { test }\end{array}$ & $\begin{array}{l}\text { Forward citations and } \\
\text { market value of the } \\
\text { company, have a robust } \\
\text { connection with the patent } \\
\text { value. }\end{array}$ \\
\hline $\begin{array}{l}\text { (Wang, García, } \\
\text { Guijarro, \& } \\
\text { Moya, 2011) }\end{array}$ & \begin{tabular}{|l|} 
Patent \\
ranking
\end{tabular} & $\begin{array}{l}\text { The number of forwarding } \\
\text { and backward citations }\end{array}$ & $\begin{array}{l}\text { PageRank } \\
\text { Algorithm }\end{array}$ & $\begin{array}{l}\text { Patent citations are } \\
\text { significant in determining } \\
\text { their priority. }\end{array}$ \\
\hline (Carte, 2005) & $\begin{array}{l}\text { Prioritizing } \\
\text { patents in } \\
\text { the patent } \\
\text { portfolio }\end{array}$ & $\begin{array}{l}\text { A number of patents, } \\
\text { age of patents, forward } \\
\text { citations, backward } \\
\text { citations, ... }\end{array}$ & \begin{tabular}{|l|} 
Goal \\
programming
\end{tabular} & $\begin{array}{l}\text { Using quantitative } \\
\text { and qualitative criteria } \\
\text { alongside each other and } \\
\text { using MADM approaches } \\
\text { increase the accuracy } \\
\text { of valuation. } \\
\end{array}$ \\
\hline $\begin{array}{l}\text { (Lee \& Sohn, } \\
\text { 2016) }\end{array}$ & $\begin{array}{l}\text { Patent } \\
\text { valuation }\end{array}$ & $\begin{array}{l}\text { Alternative products, } \\
\text { design around, breadth } \\
\text { of claims, ... }\end{array}$ & \begin{tabular}{|l} 
maximum \\
achievable \\
profit method
\end{tabular} & Valuation of patents. \\
\hline
\end{tabular}


As previously mentioned, background and literature review show that the use of traditional patent valuation approaches such as costoriented (Drews, 2001), market-oriented (Daryl \& Drews, 2006), income-oriented (Kamiyama, Sheehan, \& Martinez, 2006) and real option (Pitkethly, 1999) have many shortcomings (Lee, Park, \& Jang, 2015; Mattei, 2009) including the need for simultaneous attention to different financial and non-financial criteria together for each of the patents (Wang, García, Guijarro, \& Moya, 2011; Hong, Seo, Kim, \& Kang, 2010; Hytönen \& Jarimo, 2010); and the necessity of using the opinions of experts in determining the value of patents and determining the criteria affecting the value of patents in the technological field (Grimaldi, Cricelli, Di Giovanni, \& Rogo, 2015; Ha, Liu, Cho, \& Kim, 2015; Park \& Park, 2004; Collan, Fedrizzi, \& Luukka, 2013). Over the past few years, the capabilities of MADM methods have been emphasized to address these problems and deficiencies (Collan, Fedrizzi, \& Luukka, 2013; Chiu \& Chen, 2007; Wang, García, Guijarro, \& Moya, 2011; Hashemkhani Zolfani, Zavadskas, \& Turskis, 2013). However, while there has been an emphasis on the use of the MADM approach by researchers, there have not been many types of research in this regard. On the other hand, the review of Tab. 1 shows that there is not much agreement among researchers about the criteria for valuation and prioritization of patents. However, so far, many studies have been conducted to identify these criteria. Hence, in this paper, we first extract a list of patent evaluation criteria based on a systematic background review of the patents and then categorize them in the form of fuzzy Delphi methodology considering the views of experts to suggest a comprehensive model for patent evaluation.

According to the role of experts in this process, in addition to comprehensiveness, the developed model is consistent with the case study conditions (patents in the field of nanotechnology in Iran). Further, given that many of the MADM methods used in past researches (such as AHP and TOPSIS) (Zavadskas, Mardani, Turskis, Jusoh, \& Nor, 2016; Aouadni, Rebai, \& Turskis, 2017) are time-consuming and have computational complexity, in this research, we offer to use the SWARA and ARAS methods, which in addition to easiness, have the necessary efficiency and can genuinely consider the views of the experts in the evaluation process. Finally, by reviewing the previous articles in the MADM field, it can be seen that the evaluation of alternatives is usually performed based on expert opinions. It has led to the loss of the benefits of methods such as patent mining, which utilize real patent data. In this regard, this study attempts to evaluate patents based on a variety of criteria considering real data recorded in patent ID and to integrate expert opinions and actual data as a basis for final ranking. (Zolfani, Yazdani, \& Zavadskas, 2018).

\section{Research Methodology}

As described in the previous sections, this study aimed to provide a framework to prioritize and value patents. The steps taken in this direction are shown in Fig. 1.

Based on this flowchart, in the first step, articles and previous studies are reviewed to find the indicators of patent valuation and prioritization. Subsequently, these indicators are categorized and aggregated using the categories presented in the articles and utilizing the opinions of technology management experts and professors as well as Iran Nanotechnology Initiative Council experts in the form of Delphi method. After finalization of the indicators, a questionnaire on the weighting of indicators is prepared and completed with the assistance of experts in the field of nanotechnology and technology management. Then, using the MADM method of SWARA, the weight of each indicator and dimension is obtained. The total number of experts was 7 , including university professors in the field of technology management, nanotechnology specialists in the nanotechnology corridor and specialists from Iran Nanotechnology Initiative Council. After the finalization of the indicators and the framework for prioritizing and valuing the patents, patents registered in 2016 at the document registration office in the field of nanoscience have been investigated and selected as the case study. Considering the importance of the field of nanotechnology, many successes in this area in recent years, and the emphasis of the high-level documents of Iran on the development of this category of technologies, the nanotechnology area is chosen for investigation. Also, since this research has been designed to prioritize and value non-commercialized patents and to decide on the priority of investment for them, the 


\section{Fig. 1: The process of conducting research}

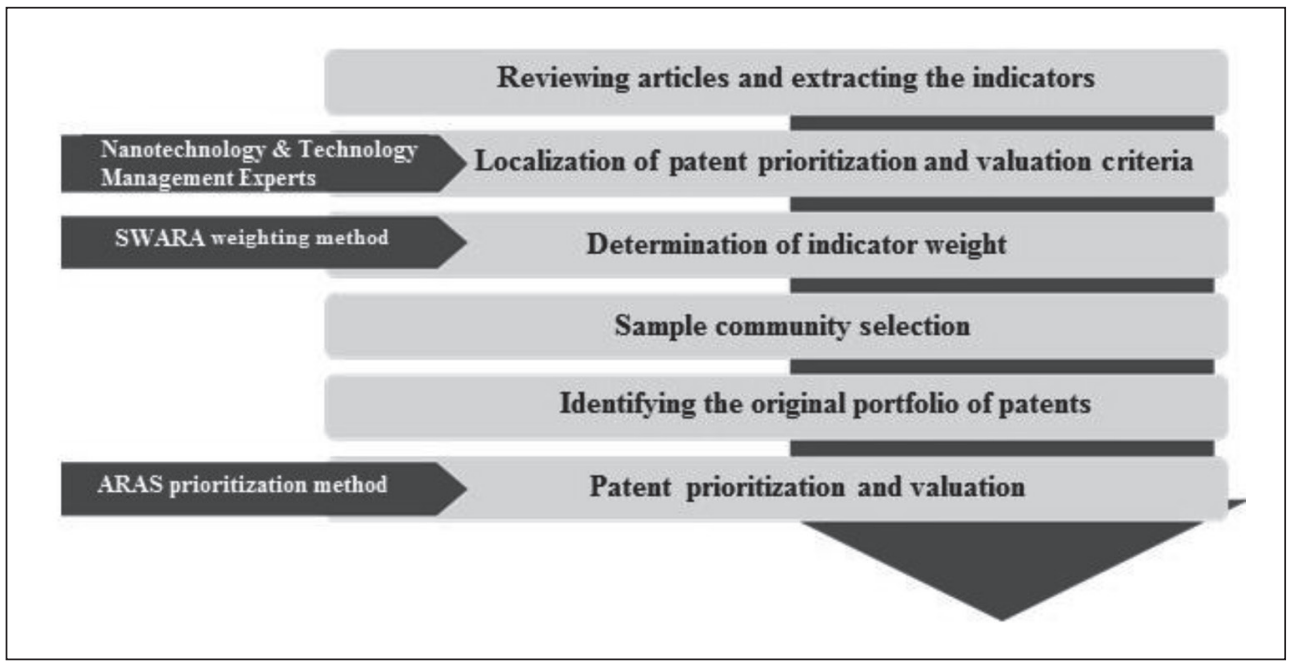

Source: own

patents of 2016 in the field of nanotechnology have been used. However, if the patents of previous years were used, experts' opinions would move towards commercialized patents.

To extract information about each of the indicators for each of the patents, a questionnaire was prepared for each patent and information on its qualitative indicators was collected and received by the experts of the field of nanotechnology patents and nanotechnology corridor as teamwork. In parallel, information about quantitative indicators is also extracted by the researcher from the text of the description of the inventions. Finally, the final matrix of the data for each of the 12 patents, examined in each of the indicators, has been completed. Finally, the value and priority of each of the patents are obtained using the MADM approach, ARAS.

\subsection{The SWARA Weighting Method}

In the SWARA method, the highest rank indicates the most valuable criterion, while the lowest level shows the least important criteria. After that, the average of ranking values is taken to determine the final ranking (Keršulienè \& Turskis, 2011). The capability of the SWARA method to evaluate expert precision about the criteria is considered to be its significant advantage (Keršuliene, Zavadskas, \& Turskis,
2010). Furthermore, experts can consult each other, and such consultation improves the accuracy of this method (Zolfani \& Saparauskas, 2013). The approach leads to improved decision-making in a wide range of situations and a more appropriate ranking of the criteria for essential goals. The SWARA provides benefits compared to other weighting tools and methods. It handles the ability for estimation of experts' opinion about criteria importance ratio in determining the weights. Besides, it has the benefit of coordinating and gathering information from experts and is user-friendly, uncomplicated, and simple, in which the experts can efficiently work together, and finally, it explores the problem priorities according to company policies (Zolfani, Yazdani, \& Zavadskas, 2018).

Hence, SWARA can be considered as a proper method to make policies and decisions at higher levels of the organization (Zolfani \& Saparauskas, 2013). The model developed by other ways, such as AHP and ANP (Turskis, Lazauskas, \& Zavadskas, 2012; Medineckiene, Zavadskas, Björk, \& Turskis, 2015), Eckenrode's rating (Turskis, Dzitac, Stankiuviene, \& Šukys, 2019), Entropy (Šaparauskas, Zavadskas, \& Turskis, 2011) is based on criteria and priorities, but model developed by SWARA is based on 


\section{Business Administration and Management}

the situation, preferences and weights. In some previous studies including (Hasan Aghdaie, Hashemkhani Zolfani, \& Zavadskas, 2013; Heidary Dahooie, Beheshti Jazan Abadi, Vanaki, \& Firoozfar, 2018; Zolfani, Esfahani, Bitarafan, Zavadskas, \& Arefi, 2013), the SWARA method has been applied to various decision-making problems. Below is a summary of the main steps of this method:

Step 1: Sorting criteria based on expert opinions. The most important criterion is ranked first, and less critical criteria are in the next levels.

Step 2: Determining the relative importance of each criterion. The relative importance of each measure is determined concerning the previous criteria. $S_{j}$ denotes this relative importance.

Step 3: Calculating $K_{j}$, a relative importance function for each criterion. This coefficient is calculated using Eq. (1):

$$
K_{j}=S_{j}+1
$$

Step 4: Calculating the initial weight of each criterion, which can be determined using Eq. (2):

$$
w_{j}=\frac{w_{j-1}}{K_{j}}
$$

Step 5: Determining the final weight of each criterion. It is the final step in the SWARA method, in which the final weight of each criterion, the normalized weight, is obtained using Eq. (3):

$$
q_{j}=\frac{w_{j}}{\sum w_{j}}
$$

The ARAS method, a tool for MADM, has been very much considered, due to the theory that there is a fair understanding of the complex phenomena of the world through simple relative comparisons (Zavadskas \& Turskis, 2010; Zavadskas, Turskis, \& Vilutiene, 2010; Heydari, Mohammadi, Vanaki, \& Jamali, 2017; Štreimikienè, Šliogerienè, \& Turskis, 2016; Zavadskas, Turskis, \& Bagočius, 2015). It is a relatively simple but effective MCDM method (Ecer, 2018). The ARAS method uses the concept of optimality degree to achieve rankings. The optimality degree is equal to the sum of the weighted normalized values of the criteria according to each alternative divided by the sum of the weighted normalized values of the best choice.

Step 1: Generating a decision matrix $\mathrm{m} \times \mathrm{n}$, where $m$ and $n$ denote alternatives and criteria, respectively:

$X=\left[\begin{array}{ccccc}x_{01} & \ldots & x_{0 j} & \ldots & x_{0 n} \\ \vdots & \ddots & \vdots & \ddots & \vdots \\ x_{i 1} & \ldots & x_{i j} & \ldots & x_{i n} \\ \vdots & \ddots & \vdots & \ddots & \vdots \\ x_{m 1} & \ldots & x_{m j} & \ldots & x_{m n}\end{array}\right] ; i=\overline{0, m} ; j=\overline{1, n}$

$x_{i j}$ denotes the performance value of the $i$-th alternative concerning the $j$-th criterion. Also, $x_{0 i}$ represents the optimum value for the $j$-th criterion. The unknown optimum value for the variable $j$ in some cases can be obtained using Eq. (4):

$$
\begin{aligned}
& \text { when } \max _{i} x_{i j} \text { is optimal, } x_{0 j}=\max _{i} x_{i j} \\
& \text { when } \min _{i} x_{i j}^{*} \text { is optimal, } x_{0 j}=\min _{i} x_{i j}^{*}
\end{aligned}
$$

Meanwhile, if decision-makers use Likerttype scale it is equal to the maximal value in the scale. In this research, the maximal scale value is Very High and equals to 5. For cost type criteria, if the optimal value is unknown, the optimal value equals to the 0.8 of minimal $j$-th criterion value of considered options, while the optimal value of profit criterion equals 1.2 of maximal criterion $j$-th criterion value of considered options.

In general, the alternative evaluation values concerning criteria $\left(x_{i j}\right)$ and each criterion weight $\left(w_{j}\right)$ form the decision matrix entries. Since each criterion has a certain dimension, to carry out a comparative analysis and to avoid potential consequences of different aspects, dimensionless quantities should be obtained. For this purpose, weighted values are divided by the optimal value obtained from Eq. (5). Several methods can be used to determine useful dimensionless values, which are described below. Normalization is a process for converting the original values of the decision matrix to values in the interval $[0,1]$ or $[0 ; \infty]$.

Step 2: Normalizing the original entries for all criteria. $\bar{x}_{i j}$ denotes the normalized entries of the matrix obtained. 


$$
\bar{X}=\left[\begin{array}{ccccc}
\bar{x}_{01} & \ldots & \bar{x}_{0 j} & \ldots & \bar{x}_{0 n} \\
\vdots & \ddots & \vdots & \ddots & \vdots \\
\bar{x}_{i 1} & \ldots & \bar{x}_{i j} & \ldots & \bar{x}_{i n} \\
\vdots & \ddots & \vdots & \ddots & \vdots \\
\bar{x}_{m 1} & \ldots & \bar{x}_{m j} & \ldots & \bar{x}_{m n}
\end{array}\right] ; i=\overline{0, m} ; j=\overline{1, n}
$$

Since there are two types of criteria named as benefit type and cost type, the entries can be normalized positively or negatively according to Eq. (7) and (8), respectively.

$$
\begin{aligned}
& \bar{x}_{i j}=\frac{x_{i j}}{\sum_{i=0}^{m} x_{i j}} \\
& x_{i j}=\frac{1}{x_{i j}^{*}} \bar{x}_{i j}=\frac{x_{i j}}{\sum_{i=0}^{m} x_{i j}}
\end{aligned}
$$

The framework resulting from the use of dimensionless quantities makes it possible to compare each criterion with all others.

Step 3: Calculating the weighted normalized decision matrix $(\hat{X})$. The weight values are determined using subjective methods and applied to the normalized decision matrix $\bar{X}$. These weights should satisfy the following equations:

$$
\begin{gathered}
0<w_{j}<1, \sum_{j=1}^{n} w_{j}=1 \\
\hat{X}=\left[\begin{array}{ccccc}
\hat{x}_{01} & \ldots & \hat{x}_{0 j} & \ldots & \hat{x}_{0 n} \\
\vdots & \ddots & \vdots & \ddots & \vdots \\
\hat{x}_{i 1} & \ldots & \hat{x}_{i j} & \ldots & \hat{x}_{i n} \\
\vdots & \ddots & \vdots & \ddots & \vdots \\
\hat{x}_{m 1} & \ldots & \hat{x}_{m j} & \ldots & \hat{x}_{m n}
\end{array}\right] ; i=\overline{0, m} ; j=\overline{1, n} \\
\hat{x}_{i j}=\bar{x}_{i j} \times w_{j} ; i=\overline{0, m}
\end{gathered}
$$

where $\bar{x}_{i j}$, represents the normalized value for $i$-th alternative and $w_{j}$ denotes the weight value for the $j$-th criterion. Then, the optimality function value, $S_{i}$, can be calculated using Eq. (11):

$$
S_{i}=\sum_{j=1}^{n} \hat{x}_{i j} ; i=\overline{0, m}
$$

The ARAS logic states that the highest optimality function value indicates the best and the lowest optimality function value indicates the worst alternative. Accordingly, alternatives can be ranked based on the value of $S_{i}$. The degree of utility $K_{i}$ for the alternative $A_{i}$ can be determined by comparing each alternative with the best/optimal alternative $S_{0}$, as follows:

$$
K_{i}=\frac{S_{i}}{S_{0}} ; i=\overline{0, m}
$$

where $S_{0}$ and $S_{i}$ are calculated by Eq. (11). $K_{i}$ is applied to rank all the alternatives, which is placed on $[0,1]$.

\subsection{Data Set Information}

Nanotechnology is a discipline of applied science and technology that covers a wide range of topics. Nanotechnology is the understanding and application of new properties of materials and systems in this dimension that show new physical effects - mostly influenced by the overcoming of quantum properties on classical properties (Poole Jr \& Owens, 2003). Iran has ranked 29th in 2012 in terms of the number of patents released on nanotechnology (Nanomagazine, 2012). Besides, as noted earlier, the importance of the field of nanotechnology has been highlighted in the high-level documents of Iran. Also, the significant progress of Iran in this field has led to the selection of this field as a case study. On the other hand, given that the proposed framework in this paper aims to prioritize and valuation of non-commercial patents and decide on their investment priority, patents should be selected that have not yet been commercialized. The reason for the selection of patents of 2016 for evaluation is that they have not yet been marketed. The study population included 12 patents registered in the Iranian Administration of Registration of Documents in the field of nanotechnology in 2016. These patents are provided in Tab. 2, and the specifications of each one are presented separately.

\section{Analysis of the Findings}

In this section, based on the steps described in the research methodology section, the outcomes of each level are explained.

\subsection{Localization of Patent Valuation and Prioritization Criteria}

Through the studies in the background review (Tab. 1 above), to extract the indicators for patent valuation and prioritization, a large set of these indicators has been obtained. After the aggregation of the indicators and their initial 


\begin{tabular}{|c|c|c|}
\hline Code & Patent title & Class \\
\hline $\mathrm{P} 1$ & Fabrication of tar and sitar string with graphene nanoplates & G10B \\
\hline $\mathrm{P} 2$ & $\begin{array}{l}\text { Production of nano carboxymethyl cellulose/polystyrene core-shell } \\
\text { nanocomposite to improve the properties of drilling fluids (oil and } \\
\text { gas wells) }\end{array}$ & B01J - B82B \\
\hline P3 & $\begin{array}{l}\text { Synthesis of nanoparticles of graphene oxide functionalized with } \\
\text { PSS to enhance anti-corrosion properties of epoxy coating }\end{array}$ & B82B - B01J \\
\hline $\mathrm{P} 4$ & $\begin{array}{l}\text { Preparation of Fe } 3 \mathrm{O} 4 \text { magnetic nanoparticle coated by poly ortho } \\
\text { aminophenol for extraction and measurement of codeine using gas } \\
\text { chromatography method }\end{array}$ & $\begin{array}{l}\text { C01B 31/00 - C01G } \\
49 / 00\end{array}$ \\
\hline P5 & $\begin{array}{l}\text { Creation of a SuperCapacitor based on polymer-carbon } \\
\text { nanocomposites using active electrode material of polypyrrole, } \\
\text { graphene oxide and carbon nanotubes }\end{array}$ & B01J - B82Y \\
\hline P6 & $\begin{array}{l}\text { Creation of nanostructured tantalum film using pulsed DC- PACVD } \\
\text { plasma assisted chemical vapour deposition }\end{array}$ & $\begin{array}{l}\text { C22C 27/02 - B82Y - } \\
\text { C23C 16/00 }\end{array}$ \\
\hline $\mathrm{P} 7$ & $\begin{array}{l}\text { Synthesis of titanium-silica /ascorbic acid/cobalt (TiO2-SiO2 } \\
\text { / AA / Co) nanocatalyst for conversion and separation of } \\
\text { dibenzothiophene in the oxidation desulfurization process }\end{array}$ & $\begin{array}{l}\mathrm{B} 01 \mathrm{~J} 21 / 06-\mathrm{B} 01 \mathrm{~J} \\
23 / 75-\end{array}$ \\
\hline P8 & $\begin{array}{l}\text { The sacrificial polymer templates for fabrication of metal and } \\
\text { ceramic micro/nano networks }\end{array}$ & D06M 10/00 \\
\hline P9 & $\begin{array}{l}\text { Synthesis of carbon nanotubes functionalized with 3-amino- } \\
\text { dihydroxybenzoic-indeno-furan as heavy metal adsorbent }\end{array}$ & C02F 1/62 - B82Y \\
\hline P10 & $\begin{array}{l}\text { Platinum /sulfonated graphene nanoparticles as catalyst ink for } \\
\text { proton exchange fuel cells }\end{array}$ & H01M 4/92 - B01J 23/42 \\
\hline P11 & $\begin{array}{l}\text { Nanocapsules containing tarragon (Artemisia dracunculus) } \\
\text { essential oil as an effective herbal larvicide against Anopheles } \\
\text { stephensi }\end{array}$ & $A 01 N$ 65/12 - B82Y 5/00 \\
\hline P12 & $\begin{array}{l}\text { Gelatin-Chitosan/Carbon Nanotube Composite Scaffolds for Bone } \\
\text { Tissue Engineering Applications }\end{array}$ & B82Y 30/00 - A61K \\
\hline
\end{tabular}

Source: own

finalization, the indicators were modified and adjusted through the Delphi method and using the opinions of experts in the two areas of technology management and nanotechnology. The indicators have been finalized during numerous meetings with these experts. To implement the Delphi method in this study, a list of experts in the field of nanotechnology and technology management was prepared at the beginning. In the next step, the criteria extracted from the literature were discussed in an interview with each of these experts and their views on each of the criteria have been received. Then, these criteria were modified based on integrated opinions and were aggregated with the revised criteria in the second interview. Following the finalization of the patent valuation and prioritization criteria, these criteria are categorized. For this purpose, the categories in the articles reviewed and discussed by three previous experts (two experts in the field of nanotechnology and one expert in the field of technology management), agreed by all the experts involved in the research. Finally, by combining the categories in the articles, the criteria are categorized in four categories: technology quality (representing the quality of registered patents that includes measures such as the number of citations, the number of claims, the degree of newness, and so on (Huang, 2016; Lee \& Sohn, 2016)), technology nature (including criteria such as 
age of patents, risk-taking level, development experience, and so on (Young-Ki, Seung-Jun, \& Seong-Taek, 2016; Chiu \& Chen, 2007; Park \& Park, 2004)), economic value (representing the cost-effectiveness amount of patents to invest in (Chiu \& Chen, 2007; Hong, Seo, Kim, \& Kang, 2010)) and commercial and market potential (reflecting the degree of competitiveness, patent position in the life cycle and the current and future patent status in the market (YoungKi, Seung-Jun, \& Seong-Taek, 2016; Kwon, Ryu, \& Park, 2013; Chiu \& Chen, 2007; Park \& Park, 2004; Lee \& Sohn, 2016)). Finally, the final indicators for valuing and prioritizing nanotechnology patents are presented in Tab. 3. This table shows that each of the criteria used in this article has been used in which of the articles reviewed in the literature.

\subsection{Determining the Weight of the Indicators}

Regarding the process described for the SWARA weighting method, a questionnaire was designed and delivered to experts following the prioritization and valuation criteria of patents. The survey was sent to the ten experts who were introduced to the researcher by the snowball method, and 7 of them completed the questionnaire. According to the equations, finally, the weight table obtained using the SWARA method is given in Tab. 4, with an accuracy of 5 decimal places. In this table, the title of each indicator is reintroduced, but from now on, their names are not mentioned and only their codes are used (See Attachment 1 to view details of the calculations).

\section{Tab. 3: Final set of research indicators (Part 1)}

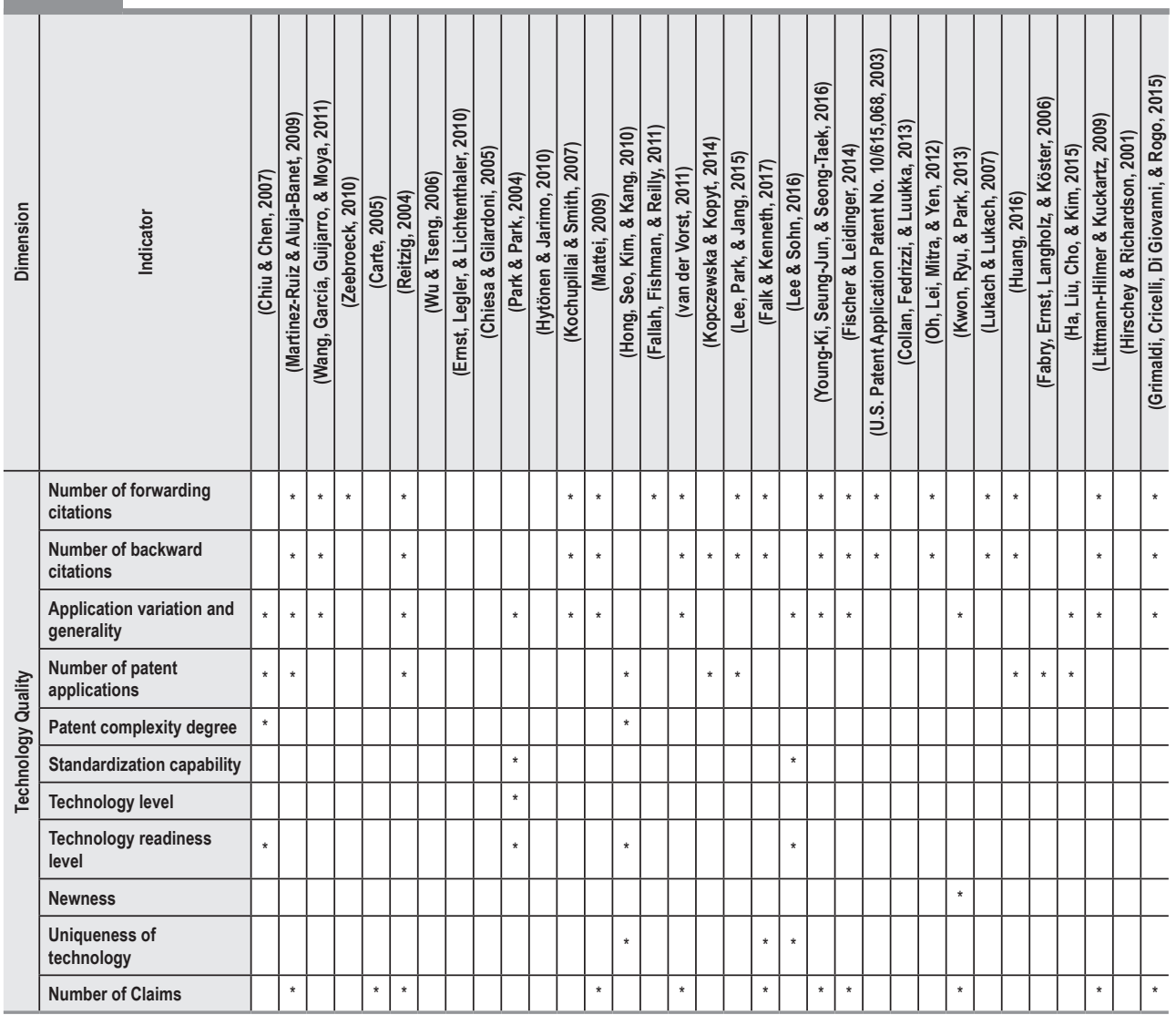




\section{Tab. 3: Final set of research indicators (Part 2)}

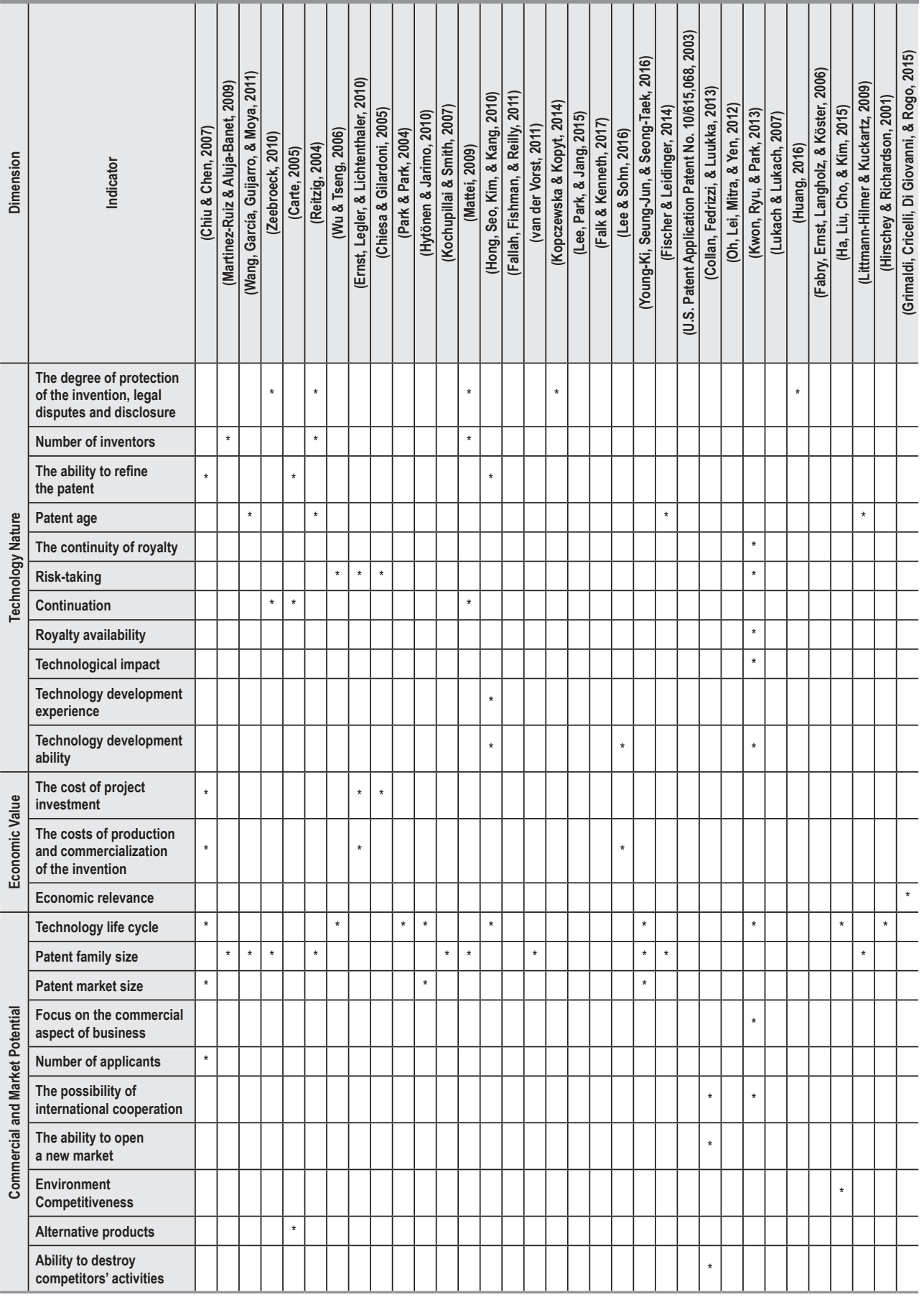


Tab. 4 shows the results of weighting the criteria for prioritizing and valuing the patents using the SWARA method. The results of this method show that the dimension $\mathrm{D}$ (commercial and market potential) with the weight of approximately 0.32 is considered as the most critical dimension and then the dimension $\mathrm{C}$ (economic value) having a weight of roughly 0.3 , a minimal difference from dimension $D$, ranked as the second most important dimension. After that, the two dimensions A (technology quality) with a weight of approximately 0.19 and $B$ (technology nature) with a weight of roughly 0.17 are placed in the third and fourth positions, respectively.

Based on the order of the most critical dimensions, the most crucial indicator in dimension $\mathrm{D}$ (commercial and market potential), is D1 (technology life cycle), the most vital indicator in dimension $\mathrm{C}$ (economic value), is C1 (the cost of project investment), the most critical indicator in the dimension A (technology quality), is A7 (technology level), and finally the most crucial indicator in $\mathrm{B}$ dimension (technology nature), the least essential dimension, is B11 (technology development ability). Among 35 indicators considered to prioritize and evaluate the patents, the most critical indicators are, C1 (the cost of project investment), C2 (the costs of production and commercialization of the invention), and C3 (economic relevance). They are placed all in economic value dimension. Then, the indicator D1 (technology life cycle) and the D3 (patent market size) is ranked fourth and fifth among the 35 indicators, respectively.

\section{Tab. 4: The final weight and priority of the indicators based on experts' opinions (Part 1)}

\begin{tabular}{|c|c|c|c|c|c|}
\hline Code & $\begin{array}{l}\text { Final weight } \\
\text { of dimension }\end{array}$ & $\begin{array}{l}\text { Final rank } \\
\text { of dimension }\end{array}$ & Indicator code & $\begin{array}{l}\text { Final weight } \\
\text { of indicator }\end{array}$ & $\begin{array}{l}\text { Final rank } \\
\text { of indicator }\end{array}$ \\
\hline \multirow{11}{*}{ A } & \multirow{11}{*}{0.19422} & \multirow{11}{*}{3} & A1 & 0.0067 & 33 \\
\hline & & & $\mathrm{A} 2$ & 0.0057 & 34 \\
\hline & & & A3 & 0.0145 & 24 \\
\hline & & & A4 & 0.0162 & 22 \\
\hline & & & A5 & 0.0090 & 32 \\
\hline & & & $\mathrm{A} 6$ & 0.0179 & 20 \\
\hline & & & A7 & 0.0319 & 8 \\
\hline & & & A8 & 0.0311 & 10 \\
\hline & & & A9 & 0.0260 & 14 \\
\hline & & & A10 & 0.0243 & 16 \\
\hline & & & A11 & 0.0094 & 31 \\
\hline \multirow{11}{*}{ B } & \multirow{11}{*}{0.16747} & \multirow{11}{*}{4} & B1 & 0.0124 & 26 \\
\hline & & & B2 & 0.0043 & 35 \\
\hline & & & B3 & 0.0101 & 28 \\
\hline & & & B4 & 0.0121 & 27 \\
\hline & & & B5 & 0.0099 & 29 \\
\hline & & & $\mathrm{B} 6$ & 0.0146 & 23 \\
\hline & & & B7 & 0.0096 & 30 \\
\hline & & & B8 & 0.0126 & 25 \\
\hline & & & B9 & 0.0201 & 18 \\
\hline & & & B10 & 0.0182 & 19 \\
\hline & & & B11 & 0.0297 & 12 \\
\hline
\end{tabular}


Tab. 4: The final weight and priority of the indicators based on experts' opinions (Part 2)

\begin{tabular}{|c|c|c|c|c|c|}
\hline Code & $\begin{array}{l}\text { Final weight } \\
\text { of dimension }\end{array}$ & $\begin{array}{c}\text { Final rank } \\
\text { of dimension }\end{array}$ & Indicator code & $\begin{array}{l}\text { Final weight } \\
\text { of indicator }\end{array}$ & $\begin{array}{c}\text { Final rank } \\
\text { of indicator }\end{array}$ \\
\hline \multirow{3}{*}{ C } & \multirow{3}{*}{0.30623} & \multirow{3}{*}{2} & $\mathrm{C} 1$ & 0.1229 & 1 \\
\hline & & & $\mathrm{C} 2$ & 0.1081 & 2 \\
\hline & & & $\mathrm{C} 3$ & 0.1039 & 3 \\
\hline \multirow{10}{*}{ D } & \multirow{10}{*}{0.3299} & \multirow{10}{*}{1} & D1 & 0.0520 & 4 \\
\hline & & & D2 & 0.0259 & 15 \\
\hline & & & D3 & 0.0456 & 5 \\
\hline & & & D4 & 0.0305 & 11 \\
\hline & & & D5 & 0.0316 & 9 \\
\hline & & & D6 & 0.0165 & 21 \\
\hline & & & D7 & 0.0359 & 6 \\
\hline & & & D8 & 0.0279 & 13 \\
\hline & & & D9 & 0.0325 & 7 \\
\hline & & & D10 & 0.0206 & 17 \\
\hline
\end{tabular}

\subsection{Patent Prioritization and Valuation}

As stated above, 12 patents of the field of nanotechnology, which was registered in 2016 in the document registration office of Iran have been prioritized. For this purpose, a questionnaire was prepared for each of the patents and information about their qualitative indicators has been compiled from a team of experts of the Iranian Nanotechnology Initiative Council and the Iranian nanotechnology corridor. Other indicators are quantitative and have been extracted from the description of the patents and documentation of the Registration Office. Since some indicators are quantitative and others are qualitative, qualitative data is converted to quantitative indicators with the help of experts and in the form of Likert spectrum and using linguistic variables so that they can be used in the process of ARAS method. Tab. 6 shows the matrix of collected data for each of the patents as a mix of quantitative and qualitative data. In these tables, the full name and the specifications of the indicators and patents have been abandoned, and only their abbreviation codes have been used. Information about each of these codes was fully explained in the sections above.

Now according to the ARAS method, prioritization and valuation of nanotechnology patents have been done. In the first step, the decision matrix is normalized, according to Eq. (6) and (7). In the next step, according to the weight obtained by the SWARA method and the normalized matrix obtained by the ARAS method, the weighted normalized matrix is obtained following Eq. (9) and (10). The final rank obtained for each of the patents, taking into account the weighted normalized matrix, is shown in Tab. 7, by Eq. (9).

Tab. 5: Linguistic scale for qualitative data

\begin{tabular}{l|c|c|c|c|c}
\multicolumn{1}{c|}{ Variable } & VL & L & M & H & VH \\
\hline Description & Very low & Low & Medium & High & Very high \\
\hline Quantity & 1 & 2 & 3 & 4 & 5 \\
\hline
\end{tabular}


Business Administration and Management

\begin{tabular}{|c|c|c|c|c|c|c|c|c|c|c|c|c|c|c|c|}
\hline & ola & 'ןeno & + & $\supset$ & $\supset$ & - & $\lessgtr$ & $ـ$ & 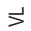 & $\Sigma$ & - & $ـ$ & - & $\Sigma$ & $I$ \\
\hline & 60 & 'eno & . & $\lessgtr$ & 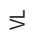 & $\Sigma$ & - & $\Sigma$ & $I$ & $I$ & $\Sigma$ & \lrcorner & $\Sigma$ & $I$ & $\Sigma$ \\
\hline & 80 & 'Ieno & + & $\lessgtr$ & $\Sigma$ & - & $\lessgtr$ & - & $\Sigma$ & - & $\lessgtr$ & \lrcorner & $\lessgtr$ & - & $\Sigma$ \\
\hline & $\angle O$ & 'ןeno & + & $\lessgtr$ & - & 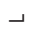 & $\lessgtr$ & ـ & - & $\lessgtr$ & $\lessgtr$ & $\Sigma$ & $\lessgtr$ & - & $\Sigma$ \\
\hline & 90 & 'ןeno & + & $\lessgtr$ & $I$ & $\lessgtr$ & $\lessgtr$ & 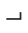 & $\Sigma$ & $\Sigma$ & $\lessgtr$ & $\lessgtr$ & - & $\Sigma$ & $\Sigma$ \\
\hline & so & 'ןno & + & $\lessgtr$ & - & - & $\lessgtr$ & I & $\Sigma$ & - & - & $ـ$ & - & - & $\lessgtr$ \\
\hline & to & 'ןno & + & $\lessgtr$ & $\Sigma$ & - & - & $\Sigma$ & $\Sigma$ & $\stackrel{I}{\lessgtr}$ & 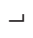 & 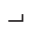 & $I$ & $\Sigma$ & $I$ \\
\hline & $\varepsilon ه$ & 'ןeno & + & $\lessgtr$ & $\triangleright$ & $\Sigma$ & - & $I$ & $\Sigma$ & - & - & $\lessgtr$ & - & $\Sigma$ & - \\
\hline & z० & ueno & + & - & $\sim$ & $\sim$ & $\sim$ & $\sim$ & $m$ & $\forall$ & - & $\sim$ & $m$ & $\sim$ & $m$ \\
\hline & 10 & 'eno & . & $\lessgtr$ & $\lessgtr$ & - & 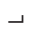 & ـ & - & $\Sigma$ & $\Sigma$ & $ـ$ & $\Sigma$ & - & $>$ \\
\hline & ๕ว & 'ןeno & + & - & \lrcorner & $\Sigma$ & - & - & - & $\Sigma$ & - & \lrcorner & $\Sigma$ & $\Sigma$ & $\Sigma$ \\
\hline & 乙כ & ' Ieno & ' & - & $\Sigma$ & - & $\Sigma$ & I & $\Sigma$ & $\Sigma$ & - & $\Sigma$ & $\Sigma$ & - & $I$ \\
\hline & 10 & 'Ieno & . & - & $\Sigma$ & $\Sigma$ & - & I & $\Sigma$ & $\Sigma$ & - & $\Sigma$ & I & - & I \\
\hline & แ & 'ןeno & + & $\Sigma$ & $\Sigma$ & I & $\Sigma$ & - & I & I & $\Sigma$ & 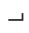 & $I$ & $I$ & $\Sigma$ \\
\hline & 이 & 'ןeno & + & $\lessgtr$ & $\lessgtr$ & - & $\lessgtr$ & 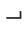 & $I$ & - & $\Sigma$ & 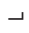 & $\Sigma$ & $I$ & - \\
\hline & 68 & 'ןno & + & $\lessgtr$ & - & - & $\lessgtr$ & I & 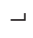 & - & - & $ـ$ & $\Sigma$ & - & $I$ \\
\hline & 88 & 'Ieno & + & $\Sigma$ & $\Sigma$ & $\Sigma$ & $\Sigma$ & $\Sigma$ & $\Sigma$ & $\Sigma$ & $\Sigma$ & $\Sigma$ & $\Sigma$ & $\Sigma$ & $\Sigma$ \\
\hline & $\angle 8$ & 'ןeno & + & 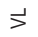 & $\Sigma$ & 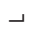 & $\lessgtr$ & - & $>$ & $\Sigma$ & $>$ & $\lessgtr$ & 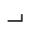 & $\lessgtr$ & $\Sigma$ \\
\hline & 98 & 'ןeno & ' & $\lessgtr$ & - & $\Sigma$ & I & $\Sigma$ & - & $\Sigma$ & $\Sigma$ & $\Sigma$ & $\Sigma$ & - & $\Sigma$ \\
\hline & sq & 'ןno & + & $\Sigma$ & $\Sigma$ & $\Sigma$ & $\Sigma$ & $\Sigma$ & $\Sigma$ & $\Sigma$ & $\Sigma$ & $\Sigma$ & $\Sigma$ & $\Sigma$ & $\Sigma$ \\
\hline & tg & ueno & ' & $\stackrel{\circ}{\grave{n}}$ & $\stackrel{\circ}{\circ}$ & $\stackrel{\circ}{\circ}$ & $\stackrel{\circ}{\circ}$ & $\stackrel{\circ}{\grave{N}}$ & $\stackrel{0}{\sigma}$ & $\stackrel{\oplus}{\sim}$ & $\stackrel{0}{i}$ & $\stackrel{\circ}{\circ}$ & $\stackrel{\circ}{\circ}$ & $\stackrel{\circ}{\circ}$ & $\stackrel{\circ}{\circ}$ \\
\hline & $\varepsilon$ & 'eno & ' & - & - & $\Sigma$ & - & I & $\stackrel{I}{>}$ & $\Sigma$ & I & I & \lrcorner & \lrcorner & $\Sigma$ \\
\hline & zg & ueno & . & $m$ & $\sim$ & $\sim$ & - & $\nabla$ & $\nabla$ & $m$ & $m$ & $\nabla$ & $m$ & $\nabla$ & $m$ \\
\hline & 18 & 'eno & + & $\Sigma$ & $\Sigma$ & $\Sigma$ & $\Sigma$ & $\Sigma$ & $\Sigma$ & $\Sigma$ & $\Sigma$ & $\Sigma$ & $\Sigma$ & $\Sigma$ & $\Sigma$ \\
\hline & UV & ueno & + & L & $\nabla$ & $r$ & $m$ & $\nabla$ & $\mp$ & $\sigma$ & $r$ & $m$ & 0 & $\nabla$ & $r$ \\
\hline & Olt & 'eno & + & $\Sigma$ & $I$ & - & $\Sigma$ & $\Sigma$ & $\Sigma$ & - & $\lessgtr$ & $ـ$ & - & - & $\Sigma$ \\
\hline & $6 \forall$ & 'eno & + & $\Sigma$ & $I$ & $\Sigma$ & I & $\Sigma$ & $\Sigma$ & - & - & $\Sigma$ & $\Sigma$ & 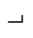 & $\Sigma$ \\
\hline & $8 \forall$ & 'Ieno & + & $\Sigma$ & $I$ & I & $\Sigma$ & $\Sigma$ & $I$ & I & I & $\Sigma$ & $\Sigma$ & $I$ & $\Sigma$ \\
\hline & $\angle \forall$ & 'ןeno & + & - & $\Sigma$ & \lrcorner & - & I & \lrcorner & - & \lrcorner & \lrcorner & $\Sigma$ & $\lessgtr$ & $I$ \\
\hline & $9 \forall$ & 'ןeno & + & - & $\Sigma$ & I & $ـ$ & $I$ & $I$ & $\stackrel{I}{>}$ & $\Sigma$ & I & $\stackrel{I}{>}$ & $\Sigma$ & I \\
\hline & s & 'ןeno & + & - & $\Sigma$ & - & \lrcorner & I & - & - & - & \lrcorner & $\lessgtr$ & - & $I$ \\
\hline$\underline{x}$ & $\forall \forall$ & ueno & + & - & $\sim$ & $\sim$ & $\sim$ & $\sim$ & $m$ & $\forall$ & - & $\sim$ & $m$ & $\sim$ & $m$ \\
\hline E & $\varepsilon \forall$ & ueno & + & - & $\sim$ & $\sim$ & - & $\nabla$ & $m$ & $\sim$ & $\sim$ & $\sim$ & $\sim$ & - & - \\
\hline 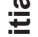 & $z \forall$ & 'ueno & + & 0 & 0 & 0 & 0 & 0 & 0 & 0 & 0 & 0 & 0 & 0 & 0 \\
\hline & IV & ueno & + & 0 & 0 & 0 & 0 & 0 & 0 & 0 & 0 & 0 & 0 & 0 & 。 \\
\hline$\frac{2}{10}$ & \multicolumn{3}{|c|}{ əd $K_{\perp}$} & $\bar{\Omega}$ & న & $\cong$ & I & 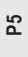 & $\ddot{2}$ & $\hat{a}$ & $\stackrel{\infty}{\not 2}$ & 8 & 웅 & $\bar{\Sigma}$ & 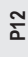 \\
\hline
\end{tabular}


Tab. 7: The final rank of each patent

\begin{tabular}{c|c|c|c|c} 
Patents & $\mathbf{S}(\mathbf{i})$ & $\mathbf{K}(\mathbf{i})$ & Rank & Final rank \\
\hline X0 & 0.114 & 1.000 & 1 & - \\
\hline P1 & 0.073 & 0.643 & 8 & 7 \\
\hline P2 & 0.079 & 0.696 & 3 & 2 \\
\hline P3 & 0.077 & 0.679 & 5 & 4 \\
\hline P4 & 0.066 & 0.585 & 12 & 11 \\
\hline P5 & 0.071 & 0.627 & 10 & 9 \\
\hline P6 & 0.077 & 0.677 & 6 & 5 \\
\hline P7 & 0.076 & 0.670 & 7 & 6 \\
\hline P8 & 0.069 & 0.608 & 11 & 12 \\
\hline P9 & 0.066 & 0.583 & 13 & 8 \\
\hline P10 & 0.072 & 0.633 & 9 & 3 \\
\hline P11 & 0.078 & 0.690 & 4 & 1 \\
\hline P12 & 0.081 & 0.714 & 2 & \\
\hline
\end{tabular}

Concerning the process of prioritizing 12 nanotechnology patents using the ARAS prioritization method, the results have been shown in Tab. 7. These results indicate that patent P12, titled as "Gelatin-Chitosan/Carbon Nanotube Composite Scaffolds for Bone Tissue Engineering Applications" should be identified as the most valuable patent. Patent P2 titled as "Production of nano carboxymethyl cellulose/ polystyrene core-shell nanocomposite to improve the properties of drilling fluids (oil and gas wells)" is ranked second and patent P11 titled as "Nanocapsules containing tarragon (Artemisia dracunculus) essential oil as an effective herbal larvicide against Anopheles stephensi" is ranked third. These patents are selected as patents with higher priority and value because of their more top ranking in terms of the ability to refine the patent, technological impacts, commercial patent aspects, and the ability to open new markets.

\section{Conclusion}

\section{Findings}

Research and development units of organizations are working towards new patents to maintain their competitive advantage (Grimaldi, Cricelli, Di Giovanni, \& Rogo, 2015; Huang, 2016). Patents, as one of the most significant achievements of this effort and in the form of valuable assets for organizations, require management and decision making (Fabry, Ernst, Langholz, \& Köster, 2006). Prioritizing and valuing patents helps organizations to identify their technology strategy (Grimaldi, Cricelli, Di Giovanni, \& Rogo, 2015). As previously stated, the adoption of this decision has many complications and requires the consideration of different dimensions of the subject (Chiu \& Chen, 2007). Given the weaknesses in the traditional approaches of patent valuation, researchers have proposed multi-attribute decision approach for this purpose (Collan, Fedrizzi, \& Luukka, 2013; Chiu \& Chen, 2007; Wang, García, Guijarro, \& Moya, 2011). Therefore, this study aimed to provide a framework for prioritizing and valuing Iranian nanotechnology patents using multiattribute decision-making methods. For this purpose, in the first step, the articles focused on the field of patent prioritization and valuation were thoroughly reviewed, and indicators extracted. Then, according to views of experts, these indicators were localized. Based on the final model, the localized indicators were divided into four categories of technology quality, technology nature, economic value and commercial and market value.

In the second step, to calculate the importance and weight of each of the indicators, 
SWARA weighting method was used. In the next section, 12 patents registered in 2016 at the document registration office of Iran in the field of nanotechnology were investigated and selected. These 12 patents were selected as the research community. Finally, ARAS method was used to prioritize these patents.

The results of the SWARA method show that the dimension $\mathrm{D}$ (commercial and market potential) is the most critical dimension and the dimension $\mathrm{C}$ (economic value), with very little difference, is the next important dimension. Subsequently, the two dimensions A (technology quality) and $B$ (technology nature) are in the third and fourth place, respectively. Among the indicators, five indicators are the essential indicators including $\mathrm{C} 1$ (project investment cost), C2 (the costs of production and commercialization of invention), C3 (economic relevance), D1 (technology life cycle) and D3 (patent market size). The five indicators with the lowest importance, weighted less than 0.01 , are B7 (continuation), A11 (number of claims), A5 (patent complexity), A1 (number of forwarding citations), A2 (number of backward citations) and B2 (number of inventors), respectively.

Given that the economic value dimension indicators, which include the cost of project investment, the costs of invention production and commercialization, and the economic relevance, have been selected as three important indicators among the 35 finalized indicators; it is suggested that inventors pay special attention to these dimension indicators and their management. It can be argued that inventors need to review and evaluate the costs of investment in the invention before they are registered. It means that the inventor will have to consider and decide on the economic justification and the degree of proportionality of his invention for future investments before spending on patent registration at internal and external databases. After the economic value dimension indicators, the technology life cycle appears as the fourth important indicator. The importance of this indicator suggests that inventors must estimate the life cycle of their technology compared to the lifecycle of other similar technologies before spending on their patents. According to these estimates, the inventors find that the cost of the patent and then the search for the right investor will give them enough money or will waste their time and money.
One of the points requiring the attention of the inventors, at the stage of writing invention description and statement of claims, is description and interpretation of the patent market. This indicator is the fifth most important indicator. The inventors should carefully examine all their patent applications and explain the full description of their invention and examples of its use in various industries before submitting their patent. Another point that is important in demonstrating the details of the invention is the ability to create markets in the future. As attention to the lifecycle of technology is essential and should be of interest to inventors, evaluation of alternative products is also crucial. It means that the lower the number of alternative products for the invention, the more chance of success, the more potential of commercialization and the more demand for the invention will be. The high weight of the indicators of alternative products, the number of applicants and the focus on the commercial aspect of business in this study indicate the importance of addressing this issue. Finally, the results of patent valuation and prioritization indicate that among the 12 patents examined, 3 patents are the most valuable, titled as "Gelatin-Chitosan/Carbon Nanotube Composite Scaffolds for Bone Tissue Engineering Applications", "Production of nano carboxymethyl cellulose/polystyrene coreshell nanocomposite to improve the properties of drilling fluids (oil and gas wells)"and "Nanocapsules containing tarragon (Artemisia dracunculus) essential oil as effective herbal larvicide against Anopheles stephensi".

\section{Future Study}

Regarding the discussed issues and past research gaps highlighted in the background review section, the current research innovation can be expressed as three main categories:

- Providing a patent evaluation model that is sufficiently comprehensive compared to the models proposed in previous studies and is localized and adapted to the conditions of the case study.

- Use of relatively new MADM methods increases the efficiency and effectiveness of the decision-making process by experts.

- They consider the actual data contained in the patent ID for calculating the patent performance score in some quantitative indicators, as well as take advantage of 
own expertise and experience in evaluating the qualitative criteria associated with the patent.

To explain the localized model of valuation and prioritization of patents, we can use the indicators obtained in this research and the modeling approaches such as structural equation approach. On the other hand, since many of the criteria used in this paper are qualitative and the opinions of the experts are involved in them, it is recommended to use fuzzy or grey numbers in future researches. Also, considering the criteria such as the ability to create new markets, the ability to destroy competitors' activities and other criteria of this kind, and since the opinions of experts for these criteria are uncertain, more modern methods of multi-attribute decision making such as HF and IVIF can be used in future researches to consider uncertainty conditions.

\section{References}

Anderson, A. (1992). The Valuation of Intangible Assets. London: Economist Intelligence Unit.

Aouadni, S., Rebai, A., \& Turskis, Z. (2017). The Meaningful Mixed Data TOPSIS (TOPSIS-MMD) Method and its Application in Supplier Selection. Studies in Informatics and Control, 26(3), 353-363. https://doi.org/10.24846/v26i3y201711.

Bishop, J. C. (2003). Challenge of Valuing Intellectual Property Assets. Northwestern Journal of Technology and Intellectual Property, 1(1), 59-65

Carte, N. (2005). The maximum achievable profit method of patent valuation. International Journal of Innovation and Technology Management, 2(2), 135-151. https://doi. org/10.1142/S0219877005000435.

Chiesa, V., \& Gilardoni, E. (2005). The valuation of technology in buycooperate-sell decisions. European Journal of Innovation Management, 8(1), 5-30. https://doi.org/10.1108/14601060510578556.

Chiu, Y.-J., \& Chen, Y.-W. (2007). Using AHP in patent valuation. Mathematical and Computer Modelling, 46(7), 1054-1062. https:// doi.org/10.1016/j.mcm.2007.03.009.

Collan, M., Fedrizzi, M., \& Luukka, P. (2013). A multi-expert system for ranking patents: An approach based on fuzzy pay-off distributions and a TOPSIS-AHP framework. Expert Systems with Applications, 40(12), 4749-4759. https://doi.org/10.1016/j.eswa.2013.02.012.
Dahooie, J., Vanaki, A., Mohammadi, N., \& Firoozfar, H. (2018). Selection of optimal variant route based on dynamic fuzzy GRA. Decision Science Letters, 7(4), 523-534. https://doi. org/10.5267/j.dsl.2017.11.004.

Daryl, M., \& Drews, D. (2006). Intellectual property valuation techniques. The Licensing Journal, 16.

Drews, D. (2001). The cost approach to IP valuation: Its uses and limitations. IP Metrics Intellectual Property Valuation. Retrieved from http://ipmetrices.net/Cost20.

Ecer, F. (2018). An integrated Fuzzy AHP and ARAS model to evaluate mobile banking services. Technological and Economic Development of Economy, 24(2), 670-695. https://doi.org/10.3846/20294913.2016.1255275.

Ernst, H., Legler, S., \& Lichtenthaler, U. (2010). Determinants of patent value: Insights from a simulation analysis. Technological Forecasting \& Social Change, 77(1), 1-19. https://doi.org/10.1016/j.techfore.2009.06.009.

Fabry, B., Ernst, H., Langholz, J., \& Köster, M. (2006). Patent portfolio analysis as a useful tool for identifying R\&D and business opportunities - an empirical application in the nutrition and health industry. World Patent Information, 28(3), 215-225. https://doi. org/10.1016/j.wpi.2005.10.004.

Falk, N., \& Kenneth, T. (2017). Patent Valuation with Forecasts of Forward Citations. Journal of Business Valuation and Economic Loss Analysis, 12(1), 101-121. https://doi. org/10.1515/jbvela-2016-0002.

Fallah, M. H., Fishman, E., \& Reilly, R. R. (2011). Forward patent citations as predictors for patent valuation. International Journal of Intellectual Property Management, 4(3), 165-178. https://doi.org/10.1504/IJIPM.2011.041081.

Fischer, T., \& Leidinger, J. (2014). Testing patent value indicators on directly observed patent value - An empirical analysis of Ocean Tomo patent auctions. Research Policy, 43(3), 519-529. https://doi.org/10.1016/j. respol.2013.07.013.

Grimaldi, M., Cricelli, L., Di Giovanni, M., \& Rogo, F. (2015). The patent portfolio value analysis: A new framework to leverage patent information for strategic technology planning. Technological Forecasting and Social Change, 94, 286-302. https://doi.org/10.1016/j. techfore.2014.10.013.

Ha, S. H., Liu, W., Cho, H., \& Kim, S. H. (2015). Technological advances in the fuel cell vehicle: 
Patent portfolio management. Technological Forecasting and Social Change, 100, 277-289. https://doi.org/10.1016/j.techfore.2015.07.016.

Hasan Aghdaie, M., Hashemkhani Zolfani, S., \& Zavadskas, E. K. (2013). Decision making in machine tool selection: An integrated approach with SWARA and COPRAS-G methods. Engineering Economics, 24(1), 5-17. https://doi.org/10.5755/j01.ee.24.1.2822.

Hashemkhani Zolfani, S., Zavadskas, E. K., \& Turskis, Z. (2013). Design of products with both International and Local perspectives based on Yin-Yang balance theory and SWARA method. Economic Research-Ekonomska Istraživanja, 26(2), 153-166.

Heidary Dahooie, J., Beheshti Jazan Abadi, E., Vanaki, A. S., \& Firoozfar, H. R. (2018). Competency-based IT personnel selection using a hybrid SWARA and ARAS-G methodology. Human Factors and Ergonomics in Manufacturing \& Service Industries, 28(1), 5-16. https://doi.org/10.1002/hfm.20713.

Heydari, D. J., Mohammadi, N., Vanaki, A. S., \& Jamali, M. (2017). Developing proper systems for successful cloud computing implementation using fuzzy ARAS method (case study: University of Tehran faculty of new science and technology). Journal of Information Technology Management, 9(4), 759-786. https://doi.org/10.22059/JITM.2017.235339.2067.

Hirschey, M., \& Richardson, V. J. (2001). Valuation effects of patent quality: A comparison for Japanese and US firms. Pacific-Basin Finance Journal, 9(1), 65-82. https://doi. org/10.1016/S0927-538X(00)00038-X.

Hong, S. J., Seo, J. W., Kim, Y. S., \& Kang, S. H. (2010). Construction technology valuation for patent transaction. KSCE Journal of Civil Engineering, 14(2), 111-122. https://doi. org/10.1007/s12205-010-0111-y.

Huang, J.-Y. (2016). Patent portfolio analysis of the cloud computing industry. Journal of Engineering and Technology Management, 39, 45-64. https://doi.org/10.1016/j.jengtecman.2016.01.002.

Hytönen, H., \& Jarimo, T. (2010). A Scenario Approach to Patent Valuation. Citeseer. Retrieved May 31, 2019, from http://citeseerx.ist.psu.edu/ viewdoc/download?doi=10.1.1.465.6104\&rep= rep1\&type=pdf.

IP4Inno project. (2008). Valuation of Intellectual Property, Module 4.A. in the Students Handbook provided by the Hungarian Patent Office. Available from www.ip4inno.eu.
Kamiyama, S., Sheehan, J., \& Martinez, C. (2006). Valuation and Exploitation of Intellectual Property [Working Paper DSTI/DOC(2006)5, OECD Science and Technology Industry 2006/5, June 2006].

Keršulienè, V., \& Turskis, Z. (2011). Integrated fuzzy multiple criteria decision making model for architect selection. Technological and Economic Development of Economy, 17(4), 645-666. https://doi.org/10.38 46/20294913.2011.635718.

Keršuliene, V., Zavadskas, E. K., \& Turskis, Z. (2010). Selection of rational dispute resolution method by applying new step-wise weight assessment ratio analysis (SWARA). Journal of Business Economics and Management, 11(2), 243-258. https://doi.org/10.3846/jbem.2010.12.

Kochupillai, M., \& Smith, M. A. (2007). Patent valuation with consideration for emerging technologies. Journal of Intellectual Property Rights, 12(1), 154-164.

Kopczewska, K., \& Kopyt, M. (2014). Non-linear corrections in market method of patent valuation. Business and Economic Horizons (BEH), 10(3), 177-190. https://doi. org/10.15208/beh.2014.9.

Kumar, A. (1994). Intellectual Property Rights (No. 1). New Delhi: Allied Publishers.

Kwon, Y., Ryu, T. K., \& Park, J. B. (2013). Improving the Performances of Software for Rating Patent Technology: A Korean Case Study. International Journal of Software Engineering and Its Applications, 7(3), 343-352.

Lee, B. K., \& Sohn, S. Y. (2016). Patent portfolio-based indicators to evaluate the commercial benefits of national plant genetic resources. Ecological Indicators, 70, 43-52. https://doi.org/10.1016/j.ecolind.2016.05.002.

Lee, J., Park, S., \& Jang, D. (2015). Technology Valuation Using Patent and R\&D Expense Information. In International Conference on Economics and Business Management (EBM-2015) July 29-30, 2015 Phuket (Thailand) (pp. 132-134). https://doi. org/10.17758/ERPUB.ER715261.

Littmann-Hilmer, G., \& Kuckartz, M. (2009). SME tailor-designed patent portfolio analysis. World Patent Information, 31(4), 273-277. https://doi.org/10.1016/j.wpi.2008.12.003.

Lukach, R., \& Lukach, M. (2007). Ranking USPTO Patent Documents by Importance Using Random Surfer Method (PageRank) (January 1, 2007). https://doi.org/10.2139/ ssrn.996595. 
Martinez-Ruiz, A., \& Aluja-Banet, T. (2009). Toward the definition of a structural equation model of patent value: PLS path modelling with formative constructs. REVSTAT-Statistical Journal, 7(3), 265-290.

Medineckiene, M., Zavadskas, E. K., Björk, F., \& Turskis, Z. (2015). Multi-criteria decisionmaking system for sustainable building assessment/certification. Archives of Civil and Mechanical Engineering, 15(1), 11-18. https://doi.org/10.1016/j.acme.2014.09.001.

Nanomagazine. (2012). Leading Patenting Countries in Nanotechnology in 2012. Sweden: StatNano.

Oh, S., Lei, Z., Mitra, P., \& Yen, J. (2012). Evaluating and ranking patents using weighted citations. In Proceedings of the 12thACM/IEEE-CS joint conference on Digital Libraries (pp. 281-284). https://doi.org/10.1145/2232817.2232870.

Oriani, R., Mattei, T., \& Cervellati, E. M. (2009). Valuation within the context of Patent Auctions. Faculty of Economics, Department of Entrepreneurship \& Venture Capital. Luiss Guido Carli Free International University of Social Studies. Retrieved May 31, 2019, from https:// tesi.luiss.it/39/1/2009-mattei-tommaso-tesi.pdf.

Park, Y., \& Park, G. (2004). A new method for technology valuation in monetary value: procedure and application. Technovation, 24(5), 387-394. https://doi.org/10.1016/S0166-4972(02)00099-8.

Parr, R. L., \& Smith, G. V. (1994). Quantitative Methods of Valuing Intellectual Property. In M. Simensky \& L. G. Bryer (Eds.), The New Role of IntellectualProperty in Commercial Transactions (pp. 39-68). New York: Wiley.

PCT. (2011). Patent Cooperation Treaty. Geneva: WIPO.

Pitkethly, R. (1999). The valuation of patents: a review of patent valuation methods with consideration of option based methods and the potential for further research. OIPRC Electronic Journal of Intellectual Property Rights, WP 05/99. Retrieved May 31, 2019, from www.oiprc.ox.ac.uk/EJWP0599.html.

Poole, Jr, C. P., \& Owens, F. J. (2003). Introduction to Nanotechnology. Hoboken, $\mathrm{NJ}$ : John Wiley \& Sons.

Reitzig, M. (2004). Improving patent valuations for management purposes-validating new indicators by analyzing application rationales. Research Policy, 33(6-7), 939-957. https://doi.org/10.1016/j.respol.2004.02.004.

Šaparauskas, J., Zavadskas, E. K., \& Turskis, Z. (2011). Selection of facade's alternatives of commercial and public buildings based on multiple criteria. International Journal of Strategic Property Management, 15(2), 189-203. https://doi.org/10.3846/1648715X.2011.586532.

Sivilevičius, H., Zavadskas, E. K., \& Turskis, Z. (2008). Quality attributes and complex assessment methodology of the asphalt mixing plant. Baltic Journal of Road \& Bridge Engineering, 3(3), 161-166. https://doi. org/10.3846/1822-427X.2008.3.161-166.

Spinello, R. A. (2007). Intellectual property rights. Library Hi Tech, 25(1), 12-22. https://doi. org/10.1108/07378830710735821.

Štreimikienè, D., Šliogerienè, J., \& Turskis, Z. (2016). Multi-criteria analysis of electricity generation technologies in Lithuania. Renewable Energy, 85, 148-156. https://doi. org/10.1016/j.renene.2015.06.032.

Turskis, Z., Dzitac, S., Stankiuviene, A., \& Šukys, R. (2019). A Fuzzy Group Decision-making Model for Determining the Most Influential Persons in the Sustainable Prevention of Accidents in the Construction SMEs. International Journal of Computers Communications \& Control, 14(1), 90-106. https://doi.org/10.15837/ijccc.2019.1.3364.

Turskis, Z., Lazauskas, M., \& Zavadskas, E. K. (2012). Fuzzy multiple criteria assessment of construction site alternatives for non-hazardous waste incineration plant in Vilnius city, applying ARAS-F and AHP methods. Journal of Environmental Engineering and Landscape Management, 20(2), 110-120. https://doi.org/10.3846/16486897.2011.645827.

Van der Vorst, T. (2011). Improving Statistical Patent Valuation Models Using Citation Data. TU/e, Department of Industrial Engineering and Innovation Sciences.

Wang, X., García, F., Guijarro, F., \& Moya, I. (2011). Evaluating patent portfolios by means of multicriteria analysis. Revista de Contabilidad, 14(1), 9-27. https://doi.org/10.1016/S1138-4891(11)70020-6.

WIPO. (2008). Chapter 2: Fields of Intellectual Property Protection. In WIPO Intellectual Property Handbook: Policy, Law and Use (p. 489). World Intellectual Property Organization.

Woltjen, J. (2003). U.S. Patent Application Patent No. 10/615,068.

Wu, M.-C., \& Tseng, C.-Y. (2006). Valuation of patent - a real options perspective. Applied Economics Letters, 13(5), 313-318. https://doi. org/10.1080/13504850500393477.

Young-Ki, K., Seung-Jun, L., \& Seong-Taek, P. (2016). A Study on Patent Valuation Important 
Factors: Focus on China Industry. Indian Journal of Science and Technology, 9(24), 1-6. https:// doi.org/10.17485/ijst/2016/v9i24/96150.

Zavadskas, E. K., \& Turskis, Z. (2010). Anew additive ratio assessment (ARAS) method in multicriteria decisionmaking. Technological and Economic Development of Economy, 16(2), 159-172. https://doi.org/10.3846/tede.2010.10.

Zavadskas, E. K., Antucheviciene, J., Saparauskas, J., \& Turskis, Z. (2013). MCDM methods WASPAS and MULTIMOORA: verification of robustness of methods when assessing alternative solutions. Economic Computation and Economic Cybernetics Studies and Research, 47(2), 5-20.

Zavadskas, E. K., Mardani, A., Turskis, Z., Jusoh, A., \& Nor, K. M. (2016). Development of TOPSIS method to solve complicated decision-making problems-An overview on developments from 2000 to 2015. International Journal of Information Technology \& Decision Making, 15(3), 645-682.

Zavadskas, E. K., Turskis, Z., \& Bagočius, V. (2015). Multi-criteria selection of a deepwater port in the Eastern Baltic Sea. Applied Soft Computing, 26, 180-192. https://doi. org/10.1016/j.asoc.2014.09.019.

Zavadskas, E. K., Turskis, Z., Volvačiovas, R., \& Kildiene, S. (2013). Multi-criteria assessment model of technologies. Studies in Informatics and Control, 22(4), 249-258.

Zavadskas, E., Turskis, Z., \& Vilutiene, T. (2010). Multiple criteria analysis of foundation instalment alternatives by applying additive ratio assessment (ARAS) method. Archives of Civil and Mechanical Engineering, 10(3), 123-141. https://doi.org/10.1016/S1644-9665(12)60141-1.

Zeebroeck, N. (2010). The puzzle of patent value indicators. Economics of Innovation and New Technology, 20(1), 33-62. https://doi. org/10.1080/10438590903038256.

Zolfani, S. H., \& Saparauskas, J. (2013). New application of SWARA method in prioritizing sustainability assessment indicators of energy system. Engineering Economics, 24(5), 408414. https://doi.org/10.5755/j01.ee.24.5.4526.

Zolfani, S. H., Esfahani, M. H., Bitarafan, M., Zavadskas, E. K., \& Arefi, S. L. (2013). Developing a new hybrid MCDM method for selection of the optimal alternative of mechanical longitudinal ventilation of tunnel pollutants during automobile accidents. Transport, 28(1), 89-96. https://doi.org/10.3846/16484142.2013. 782567.
Zolfani, S. H., Yazdani, M., \& Zavadskas, E. K. (2018). An extended stepwise weight assessment ratio analysis (SWARA) method for improving criteria prioritization process. Soft Computing, 22(22), 7399-7405. https://doi. org/10.1007/s00500-018-3092-2.

Assoc. Prof. Jalil Heidary Dahooie, PhD. The University of Tehran

Faculty of Management Department of Industrial Management Iran Heidaryd@ut.ac.ir

Navid Mohammadi, PhD Candidate

The University of Tehran

Faculty of Entrepreneurship Department of Entrepreneurship

Iran

Navid.m@ut.ac.ir

Assist. Prof. Mehdi Mohammadi, PhD. Corresponding author

The University of Tehran

Faculty of Management

Department of Industrial Management Iran

memohammadi@ut.ac.ir

Parisa Shahmohammadi, M.S. The University of Tehran

Faculty of Management

Department of Industrial Management Iran

p.Shahmohammadi@ut.ac.ir

Prof. Zenonas Turskis, PhD.

Vilnius Gediminas Technical University

Faculty of Civil Engineering Institute of Sustainable Construction Laboratory of Operations Research Lithuania zenonas.turskis@vgtu.It

Assoc. Prof. Jonas Šaparauskas, PhD. Vilnius Gediminas Technical University Faculty of Civil Engineering Department of Construction Management and Real Estate Lithuania jonas.saparauskas@vgtu.It 


\title{
Abstract
}

\section{A FRAMEWORK FOR VALUATION AND PRIORITIZATION OF PATENTS USING A COMBINED MADM APPROACH. CASE STUDY: NANOTECHNOLOGY}

\author{
Jalil Heidary Dahooie, Navid Mohammadi, Mehdi Mohammadi, Parisa \\ Shahmohammadi, Zenonas Turskis, Jonas Šaparauskas
}

Patent valuation and prioritization is one of the main activities for the management of intellectual property assets in an organization. So far, numerous attempts have been made to determine the value of patents, some of which have not been efficient due to ignoring some effective dimensions or considering the same importance for all aspects. To overcome this challenge, this research aims to provide a framework for valuing and prioritizing patents using a combination of MADM methods. For this purpose, first, the indicators for patent valuation and prioritization were taken from the literature and aggregated and finalized based on opinions of experts of technology management as well as nanotechnology in the form of a Delphi method. Second, the indicators were weighted, and their importance specified based on expert opinions using the questionnaire tool and stepwise weight assessment ratio analysis (SWARA) method. Third, the additive ratio assessment (ARAS) method was used to value and prioritize the patents.

For this reason, 12 nanotechnology patents, registered in 2016 at the Iranian Administration of Registration of Documents, were valued and ultimately prioritized. The results from the criteria weights indicate that commercial and market potential and the economic value should be selected as the most critical dimensions. Also, among the indicators, the project investment cost, the costs of production and commercialization and the economic relevance, were selected as the most critical indicators. Among the 12 patents examined, "Gelatin-Chitosan/Carbon Nanotube Composite Scaffolds for Bone Tissue Engineering Applications" was identified as the most valuable patent. ARAS.

Key Words: Patent valuation, nanotechnology, Multi-Attribute Decision-Making, SWARA,

JEL Classification: C44, 034.

DOI: 10.15240/tul/001/2019-3-007 